\title{
Establishment of Edinoverie and the Initial Stage of its Development in the Territory of the Ural Cossack Host
}

\author{
Tatiana S. Romaniuk* \\ Ural Federal University named \\ after the First President of Russia B. N. Yeltsin \\ 51 Lenina, Ekaterinburg, 620083, Russia
}

Received 07.11.2018, received in revised form 29.04.2019, accepted 06.05.2019

The article presents an attempt of a comprehensive research of the prerequisites and initial stage of introduction of Edinoverie in the territory of the Ural Cossack Host, based on the published and unpublished sources. It discloses some information on the initial stage of the development of Edinoverie in the territory of the Don Host, where governmental activity was not as radical, which, to a certain extent, may be explained with a more positive attitude of the local Cossacks to the official authorities. The establishment of Edinoverie for all the churches and parishes of the Ural Cossack Host was just an act of formal recognition of the Edinoverie, or a "edinoverie religious" practice existing in the Host before. Throughout the first half of the 19th century, the Ural Old Believer Cossacks went both to the Old-Rite Chapel of Dormition in Uralsk and Edinoverie churches, where, as before, the services were conducted in accordance with the old books and Old Belief rites. Therefore, it may be concluded that introduction of Edinoverie in the territory of the Ural Cossack Host was just an act of the formal conversion for the major part of Old Believers, while the actual conversions began closer to the 1840-s.

Keywords: Old Belief, Old Believers, Edinoverie, Russian Orthodox Church, the Ural Cossack Host, the Don Cossack Host, Irgiz Old Belief Monasteries, the Old Belief Chapel of Dormition.

Research area: history of Russia.

Citation: Romaniuk, T.S. (2019). Establishment of edinoverie and the initial stage of its development in the territory of the Ural Cossack host. J. Sib. Fed. Univ. Humanit. soc. sci., 12(5), 833-841. DOI: 10.17516/1997-1370-0426.

(C) Siberian Federal University. All rights reserved

* Corresponding author E-mail address: tatiana.s.romaniuk@gmail.com

ORCID: 0000-0002-7492-5300

This work is licensed under a Creative Commons Attribution-NonCommercial 4.0 International License (CC BY-NC 4.0). 


\section{Introduction}

The studies of Old Belief and Edinoverie in the territory of the Ural (Yaik) Cossacks go back to the second half of the $19^{\text {th }}$ century. In the scientific community, the problem was first set by P.I. Mel'nikov in his "Essays of Popovshchina" (Mel'nikov, 1976: 330 331, 396). The problem of Edinoverie in the South Ural expansion was also studied by such authors of the pre-Revolution period as V.N. Vitevskiy (Vitevskiy, 1877, 1878) and N.M. Chernavskiy (Chernavskiy, 1899, 1900, 1903). In the Soviet and post-Soviet times, the topic of Edinoverie in the Ural Cossack Host was almost missed out by researchers. Indirectly, the problem of priesthood and expansion of Edinoverie was mentioned in the works by N.N. Pokrovskiy (Pokrovskiy, 1974, 2005) and V.I. Baydin (Baydin, 1983, 1995: 32-46). In the monograph "Edinoverie in the Mid- $18^{\text {th }}$ - Early $20^{\text {th }}$ Centuries: All-Russian Context and Regional Specificity" by A.S. Palkin, the section on establishment of Edinoverie in the Urals presents the specificity of the Central Urals, while almost nothing is mentioned about the South Ural territories (Palkin, 2016: 104111). Therefore, at the present moment, there are no special researches dedicated to the history of the primary stage of Edinoverie expansion in the territory of the Ural Cossack Host. Without studies of this question, it is impossible to research Edinoverie as a religious, cultural, social, and political phenomenon, or the religious world outlook of the local Cossack population.

\section{Problem setting}

By the end of the $18^{\text {th }}$ century, the Old Believers faced the problem of search for clergy. It was known that the first attempts to solve the question were made by the Old Believers back in the second quarter of the $18^{\text {th }}$ century (Pokrovskiy, 1974: 67-77). Together with that, during the reign of Elizabeth Petrovna, the country held a course for gradual improvement of the relationships with the Old Believers'. In 1800, the search for compromise from both sides resulted in establishment of Edinoverie as a way of incorporating Old Believers into the official church. The rules of conversion to Edinoverie were formulated by Plato (Levshin), Metropolitan of Moscow. Edinovertsy retained their pre-Nikonian service books and rites, though obeyed to the local diocesan administration, and the priests for the churches were ordained by the ruling archbishop. This way, Old Believers could acquire a clergy rank, and the state found a way to keep

Speranskiy, M.M. (ed.) (1830). Polnoe sobranie zakonov Rossiyskoy imperii. Sobranie I [The complete Collection of Laws of the Russian Empire. Collection I]. Tip. II Otdeleniia Sobstvennoy Iego Imperatorskogo Velichestva Kantseliarii, Vol. 14. No. 10.284, 10.619, 10.889; Vol. 15. No. 11.179, 11.265. 
record of the population and to collect taxes. The establishment of Edinoverie split the "Old Belief world" into those who accepted the compromise with the authorities and those who did not (Lysogorskiy, 1915: 120).

As for the local specificity, the residents of the Ural (Yaik) Host faced an acute problem of churches and clergymen's deficit back in the early $18^{\text {th }}$ century. The Cossacks repeatedly asked for permission to build some churches ${ }^{1}$. As a result, the Decree of June 10, 1734 allowed them to build prayer houses outside the outposts. Only in 1808, it was allowed to erect chapels under to the same conditions². The same problem bothered the Cossacks of the Don Host. But the latter, besides the church construction permit, wished get church hierarchy from the local consistory. In the late $18^{\text {th }}$ - early $19^{\text {th }}$ century, the Don Cossacks requested permission to construct some churches in Cherkassk and Cossack villages Pyatiizbenskaya, Verkhne-Chirskaya, VerkhneKargalskaya and Kamyshevskaya (Lysogorskiy, 1915: 106, 111, 112, 114). In 1800, the local Cossacks managed to get a permission to establish an Old Belief monastery in an allotment in yurt Pyatiizbenskaya, in the Grushevy gully. It was supposed to be built by monk Yefimiy from the Old Belief Irgiz Monastery of Resurrection for the Don oblates, who returned from the monastery for the reason of elderly age. The monastery was planned to be financed "from donations of sponsors". However, the expectations of both Don and Ural Old Believers were not satisfied. Perhaps, the authorities feared possible conversion of the newly arranged churches back to the Old Belief. The remote locations of the Cossack residences from the diocesan administration limited the possibility of controlling the service conductors in the churches. The popularity of the Old Belief in the territories of both Hosts and constant contacts of the Don Cossacks with the Starodub runaway priests and of the Ural Cossacks with the Irgiz ones, as well as the unsuccessful attempts of forcing the population to join the official church made in the late $17^{\text {th }}-$ mid $18^{\text {th }}$ century, were the reasons why the Voronezh and Kazan Spiritual Consistories preferred to seek compromise with the Cossacks. An important role in the process was played by the local population. The state was interested in the presence of powerful and loyal military formations in the border areas, while the active anti-Old Belief measures could provoke civil disturbances. As a result, even before the official establishment of Edinoverie, in the year 1785 the Don Host was allowed to utilize old service books and follow the old rites in the official Orthodox churches; very

GAOO. Fund 172. Inv. 3. File 206. Sh. 1-2 turn; File 442; File 476; File 616. Sh. 1 turn.

GAOO. Fund. 172. Inv. 3. File 206. Sh. 1 turn, 2 turn.

RGADA. Fund 7. Inv. 2. File 3520. Sh. 2, 3, 4 turn. 
soon, the same privileges were given to the Ural Cossacks (Lysogorskiy, 1915: 42, 65; Chernavskiy, 1900: 171-172).

\section{Discussion}

To analyse the next events, it is necessary to address the prerequisites of establishment of Edinoverie in the territory of the Ural Cossack Host. After the church reform of Patriarch Nikon, the Yaik Cossacks did not accept the corrected books and the priests who conducted services under the new rites. As a result, the priests of Yaik, and since 1775 - the priests of the Ural officially recognized Orthodox churches, utilized the old books and followed the old rites in their services. The Cossacks elected future priests themselves and sent them to the local spiritual consistory for ordination. This situation raised dissatisfaction of the local church administration. Nevertheless, the right to nominate the candidates for the clergy positions was one of the privileges of the Yaik (Ural) Host, as proven by the Decree of September 12, 1755'.

This way, in the territory of residence of the Yaik (Ural) Cossacks, "Edinoverie" had been actually practiced even before it was officially established. The fact that the churches officially belonged to Orthodox Christianity, enabled the central authorities and their local representatives to officially register their parishes as official church supporters, while the major part of the population still held on to the Old Belief. The censuses of Old Believers carried out by the Kazan Diocese in the middle-second half of the $18^{\text {th }}$ century (at that moment, the scope of the Diocese covered the territory of the Yaik Host, except for Guryev Town) are very illustrative for this research. The documents provide information on the Old Believers of the Kazan Province, while the pages allocated to the Orenburg Province are left blank. The territory of the Yaik Host is not mentioned at all ${ }^{2}$. It is most likely that the census among the Yaik and Orenburg Cossacks was not held at all.

Despite the Order of June 21, 1768, prohibiting Old Believers to build chapels and churches $^{3}$, after the rebellion led by E.I. Pugachev, the Old Belief Chapel of Dormition was opened in Uralsk (Vitevskiy, 1878: 16-17). In such comfortable conditions for Old Believers, the Ural Cossacks did not have a need for conversion into Edinoverie.

Speranskiy, M.M. (ed.) (1830). Polnoe sobranie zakonov Rossiyskoy imperii. Sobranie I [The complete Collection of Laws of the Russian Empire. Collection I]. Tip. II Otdeleniia Sobstvennoy Iego Imperatorskogo Velichestva Kantseliarii, Vol. 14. No. 10.460.

RGADA. Fund 288. Inv. 1. File 288; File 817. Sh. 125-126, 128, 205.

Sobranie postanovleniy po chasti raskola [Collection of Rulings on the Split] (1875). Saint-Petersburg: Tip. M-va vnutrennikh del, 2-3. 
So the government make this step, unprecedented in the history of Edinoverie, and convert all seven officially Orthodox churches of the Ural Host to Edinoverie. As a result, three churches in Uralsk: Archangel Michael Cathedral, Kazanskaya Church, Petropavlovskaya Church; Nikolaevskaya Church in Guryev, Floro-Lavrskaya Church in Kalmykovsky Outpost, Presentation Church in Ilek, Kazanskaya Church in Sakmarsky Town changed their status. We do not know the exact time of assignment of the new statuses to the parishes. In the research by Chernavskiy, the listed churches are mentioned as belonging to Edinoverie even in the year 1800 (Chernavskiy, 1900: 276). Pamiatnik kazach'ey stariny ("Memory of the Cossack Past”) by A.B. Karpov states that the conversion years were 1803-1804 (Karpov, 1992: 59). To our mind, the conversion of churches within the same year when Edinoverie was legally established was hardly likely. The history of Russian Orthodox Church knows only one similar situation. In Romanovo-Borisoglebsk town, Archangel Orthodox Church was converted into Edinoverie in the year 1855 (Mizerov, 1883: 154). The status of Edinoverie churches to the Ural Cossack Host parishes served as the final official acknowledgement of the existing practice of service under the old books and rites at the Orthodox temples. The conversion was the evidence of unfruitfulness of all the attempts made by the central and local spiritual and secular authorities to get over Old Belief in the territory of the Host in the late $17^{\text {th }}-$ late $18^{\text {th }}$ centuries. The Ural Cossacks were registered in the parishes of the local churches and the Old Belief Chapel of Dormition (Romaniuk, 2018: 307-313). After the churches were converted, the Cossacks of the Ural Host were also formally converted from Orthodox Christianity to Edinoverie, though still remaining Old Believers.

The Old Belief Chapel of Dormition became an alternative to the enforced Edinoverie for the Host. Their unwillingness to join the official church was also proved by the multiple attempts of the local Old Believers to achieve the construction of some Old Belief churches. In 1831, the Old Believers expressed a desire to transform the Chapel of Dormition into an Old Belief church, that would be operated by the Host, not the diocesan administration. The request was not satisfied, and in 1842 the Chapel was remade into an Edinoverie church (Romaniuk, 2018: 311-312). The residents of Sakmarskaya Cossack Village went even farther than the Uralsk Cossacks. In 1845, they requested Kazanskaya Edinoverie Church to be renamed into the Old Belief Church, which was rejected ${ }^{2}$. The Don Cossacks were struggling for the same. Their

GAOO. Fund 173. Inv. 2. File 2746. Sh. 2-4.

${ }^{\mathrm{G}} \mathrm{AOO}$. Fund 173. Inv. 4. File. 8030. Sh. 1-3, 21. 
attempts to build an Old Belief chapel that would be "beyond control of the diocesan administration and the host commandment" in Cherkassk were also unsuccessful. As stated in the document, the Don Cossacks "were impossible to incorporate (into the official church - T.R.), they would still follow their ideas"1. The first Edinoverie Church of Alexander Nevsky in the territory of the Don Host was built in 1840 in Verkhne-Kargopolskaya Village. Only after that, the local Cossacks started their conversion into Edinoverie (Lysogorskiy, 1915: 145, 191). It should be noted, that for the rites the local Cossacks would address the Orthodox priests. Besides, the Don Cossacks were much more friendly to the representatives of the secular and spiritual authorities than the Ural Cossacks, which also explains the mild religious policy of the state in the region and the late emergency of the first Edinoverie church.

\section{Conclusion}

Just like for a large share of the Don Host, for the Cossacks of the Ural Host Old Belief was an integral part of their social and political life. Their willingness to keep the traditions and customs of the ancestors manifested itself not only in their lifestyle, order of service etc., but also in the retention of the old rites. That was also facilitated by the remote location and relative isolation of the Cossack communities. The Ural Cossacks' unwillingness to join Edinoverie is greatly explained with the absence of need. The Old Belief Chapel of Dormition in Uralsk, the Old Belief Monasteries of Irgiz, Old Belief Nikolskaya Chapel in Yekaterinburg remained the beglopopovtsy centres, where the desired rites could be conducted by runaway priests. The hopes for the gradual actual incorporation of the Ural Host into the official Church, expressed by the government, did not come true. The Cossacks kept sending their representatives for ordination, the churches retained the old service books and Old Believer rites, and the priests did not obey to the diocesan administration. The situation had hardly changed by the middle of the $19^{\text {th }}$ century ${ }^{2}$. It can be claimed that the enforcement of Edinoverie in the territory of the Ural Cossack Host was rather of a formal nature.

\section{Abbreviations}

GAOO - Orenburg Oblast State Archive.

RGADA - Russian State Archive of Ancient Documents. 


\section{References}

Baydin, V.I. (1983). Staroobriadchestvo Urala i samoderzhavie. Konets XVIII seredina XIX v. [Old Believers of the Urals and Autocracy. Late $18^{\text {th }}$ - mid $19^{\text {th }}$ century]: thesis for the academic degree of the Candidate of Science. Sverdlovsk, 230.

Baydin, V.I. (1995). Kto ty, Iona Kurnosyy? [Who are you, Iona Kurnosyy?]. In: Iezhegodnik NII russkoy kul'tury UrGU, 1994 [Yearbook of the Research Institute of Russian Culture, Ural State University, 1994]. Yekaterinburg, 32-46.

Chernavskiy, N. (1900). Orenburgskaia eparkhiia v proshlom i nastoiashchem [Orenburg Diocese in the Past and Present]. Orenburg: Typography of Orenburg Spiritual Consistory (Vol. 1), 346, VI.

Chernavskiy, N. (1903). Orenburgskaia eparkhiia v proshlom i nastoiashchem [Orenburg Diocese in the Past and Present]. Orenburg: Typography of Orenburg Spiritual Consistory (Vol. 2), 1058, XIV.

Karpov, A.B. (1992). Pamiatnik kazach'ey stariny. Kratkie ocherki iz istorii Ural'skogo voyska [Memory of the Cossack Past. Brief essays from the history of the Ural Host]. Uralsk, TOR, 108.

Lysogorskiy, N.V. (1915). Edinoverie na Donu v XVIII-XIX v. (po 1883 g.) [Edinoverie on the Don in the 18-19 $9^{\text {th }}$ Centuries (to 1883)]. Sergiev Posad, Typography of the Holy Trinity-St. Sergius Lavra, 800 .

Mel'nikov, P.I. (Andrei Pecherskiy) (1976). Ocherki popovshchiny [Essays of Popovshchina]. In: Sobranie sochineniy v vos'mi tomakh [Collected Works in eight volumes]. Moscow, Pravda Publishing House, 7, 558.

Mizerov, A. (1883). Edinoverie v g. Romano-Borisoglebske (kratkie istoricheskie svedeniia) [Edinoverie in the City of Romano-Borisoglebsk (Brief Historical Information)]. In: Yaroslavskie eparkhial'nie vedomosti [Yaroslavl Diocesan Statement], 20, 153-160.

Palkin,A.S.(2016).Edinoveriievseredine XVIII —nachale XXv.:obshcherossiyskiy kontekst $i$ regional'naia spetsifika [Edinoverie in the Mid 18 ${ }^{\text {th }}$ - Early $20^{\text {th }}$ Century: All-Russian Context and Regional Specifics]. Yekaterinburg, Ural University Press; Universitetskoe izdatel'stvo, 333.

Pokrovskiy, N.N. (1974). Antifeodal'nyy protest uralo-sibirskikh krest'ianstaroobriadtsev v XVIII v. [The Anti-Feudal Protest of Ural-Siberian Old Believer Peasants in the $18^{\text {th }}$ Century]. Novosibirsk, Nauka, 391.

Pokrovskiy, N.N. (2005). Puteshestviie za redkimi knigami [Journey for Rare Books]. $3^{\text {rd }}$ edition, corrected and revised. Novosibirsk, «Sova», 344. 
Romaniuk, T.S. (2018). Uspenskaia staroobriadcheskaia chasovnia Ural'skogo kazach'ego voyska [Assumption Old Believer Chapel of the Ural Cossack Host]. In: Tserkov'. Bogoslovie. Istoriia: Materialy VI Vserossiyskoi nauchno-bogoslovskoi konferentsii (Yekaterinburg, 10-12 fevralia 2018 g.) [Church. Theology. History: Proceedings of the $6^{\text {th }}$ All-Russian Scientific-Theological Conference (Yekaterinburg, February 10-12, 2018)]. Yekaterinburg Spiritual Seminary, 307-313.

Vitevskiy, V.N. (1877). Raskol v Ural'skom voyske i otnoshenie k nemu dukhovnoy $i$ voennograzhdanskoy vlasti v I polovine XVIII v. [The Split in the Ural Host and the Attitude to It of the Clerical and Military-Civilian Authorities in the 1st Half of the $18^{\text {th }}$ Century]. Kazan, Typography of the Emperor's University, 68.

Vitevskiy, V.N. (1878). Raskol v Ural'skom voyske i otnoshenie k nemu dukhovnoy $i$ voiennograzhdanskoy vlasti v kontse XVIII $i$ v XIX v. [The Split in the Ural Host and the Attitude to It of the Clerical and Military-Civilian Authorities in the late $18^{\text {th }}$ and $19^{\text {th }}$ centuries]. Kazan, Typography of the Emperor's University, 235.

\section{Учреждение единоверия и начальный этап его распространения на территории Уральского казачьего войска}

Т.С. Романюк

Уральский федеральньй университет им. первого Президента России Б. Н. Ельизина Россия, 620083, Екатеринбург, пр. Ленина, 51

В статье предпринимается попытка всестороннего исследования на основе опубликованных и неопубликованных источников предпосылок и начального этапа введения единоверия на территории Уральского казачьего войска. Приводятся некоторые сведения о начальном этапе распространения единоверия на территории Донского войска, где действия правительства не были столь радикальными, что можно в некоторой степени объяснить более лояльным отношением местных казаков к официальнымм властям. Перевод всех иерквей и их прихожан Уральского казачьего войска в единоверие стал лишь формальньм признанием существовавщей в войске еще до учреждения единоверия «единоверческой» практики. На протяжении первой половины XIX в. уральские казаки-старообрядиь продолжали обращаться в Успенскую старообрядческую часовню в Уральске, а также в единоверческие храмы, где, как и прежде, служили по старым книгам и обрядам для старообрядчев. Таким образом, можно сделать вывод, что введение на территории Уральского казачьего войска единоверия привело только к формальному переходу значительной части староверов. В то время как действительные переходы начинаются ближе к 40-м гг. ХІХ в. 
Ключевые слова: староверие, старообрядчество, единоверие, русская православная иерковь, Уральское казачье войско, Донское казачье войско, Иргизские старообрядческие монастыри, Успенская старообрядческая часовня.

Научная специальность: 07.00.02 - отечественная история. 